\title{
The Socio-Economic Impact of the Siosar Relocation Policy
}

\author{
Nina Novira, Elfayetti, Anik Juli Dwi Astuti, Rosni, Ikhsan Bayhaqi \\ \{ninanovira@unimed.ac.id ${ }^{1}$ \} \\ Department of Geography Education, Universitas Negeri Medan, Jalam Willem Iskandar, Indonesia
}

\begin{abstract}
The series of Mt. Sinabung eruption devastated the surrounding villages. This leads to the relocation policy that obliged the inhabitants of some villages to move to the Siosar Relocation Area. Extracted from their roots, the villagers must move to a new place to start their new life. This raises the question of how is the social relations of the relocated people? The villagers are also extracted from their agricultural fields. The government provides 0.5 hectares of land for agriculture. However, it is new soil, topography, temperature, and new marketing arrangements. This raises the question of how those affected the villagers' income and eventually their economy. These thus lead to another question. How do they cope with the new condition? With a qualitative approach, this study used in-depth interviews and direct observation to collect data. The result shows that both the social and economic conditions of the relocated people are in good and or are moving into good condition. They are overall confident that they are heading towards a good future.
\end{abstract}

Keywords: socio-economic impact, Siosar relocation area, good future

\section{Introduction}

The eruption of Mount Sinabung which lasted for the last three years (2013 to 2015) resulted in lands and settlements in the villages of Sukameriah, Bakerah and Simacem, Naman Teran Subdistrict being permanently damaged and very dangerous to be maintained as residential and agricultural land. A total of 370 family heads (KK) from these three villages have been relocated to other, safer places, both for settling and farming [1]. The government is responsible for implementing disaster management including post-disaster reconstruction and rehabilitation. Guaranteed fulfillment of the rights of refugee communities must be under service standards that must be sought immediately. All disaster recovery and reconstruction measures must be guided by Law Number 24 of 2007 concerning Disaster Management. Relocation is one of the efforts of the government or other groups in disaster management experienced by people who lost their homes [2]. Relocation is an alternative to provide opportunities for people living in slums, the status of the land is not legal (illegal) who live in a disaster-prone environment to reorganize life in a new place. Presidential Decree Jokowi regarding the efforts to accelerate the relocation of Sinabung refugee victims number 21 of 2015 which contains the construction of permanent residential areas in the location area and 
the construction of facilities and infrastructure in the relocation area, so far it has not been resolved properly [3].

The Government and Regency Government of Karo are completing relocation for 3331 families of Sinabung residents. 370 families of residents from Bekerah Village, Simacem Village, and Sukameriah Village have been relocated to the Siosar area. A total of 1,863 households in the process of independent relocation are expected to be completed in 2018 . While 1,098 households will be relocated to the Siosar region. Refugees who do not have to be relocated are also being built 348 temporary residential units [4]. The results of the performance evaluation of the Task Force for the Acceleration of Relocation show the lack of achievement of the policy. On the other hand, the performance of the Karo District Disaster Management Agency has not yet looked good because there are still many problems in eradicating the eruption of Mount Sinabung [5].

Facilities and infrastructure have not been resolved until now. Agricultural land in the relocation area which is the main source of livelihoods is also widely complained by the community. Means of education, the cost of living of the community's household in the evacuation which is also a matter of complaints by the people who are in the relocation area. The process of relocation of settlements tends to be slow, the economic activity of the population is hampered by displacement and the government assistance funds to the community are not enough to meet their daily needs [6]. This has an impact on the socioeconomic conditions of the people residing in the relocation area. Inadequate housing, agricultural land, facilities, and infrastructure are the main factors in the occurrence of socioeconomic impacts of the community. Therefore it is necessary to address these factors, the community can benefit from the policies provided by the government. To be able to make efforts to reduce these risks, data and information on the impact of relocation policies on the socio-economic conditions of the population are needed. The objectives of this study are to determine the impact of relocation policies on the socio-economic conditions of the people of Karo Regency.

\section{Method}

This research alternates in Siosar Relocation Area, in Karo District, North Sumatra Province. Siosar Relocation Area is geographically located at $02^{\circ} 58^{\prime} 56.9^{\prime \prime} \mathrm{LU}$ and $98^{\circ}$ $30^{\prime} 18.5$ " East, with a distance of about $23.7 \mathrm{Km}$ to Mount Sinabung, and the distance to Kabanjahe is around $17 \mathrm{Km}$ (Figure 1). The reason for choosing this research location is because Siosar Relocation Area is a relocation site for Mount Sinabung eruption victims and which is physical evidence of the relocation policy. The population of this research is the people of the Siosar Relocation Area, Karo Regency. The sampling technique was purposive sampling, which was chosen based on the consideration of informants who experienced first hand the situation and process of implementing the Mount Sinabung eruption refugee relocation policy in the Siosar Relocation Area, Karo District, North Sumatra. 


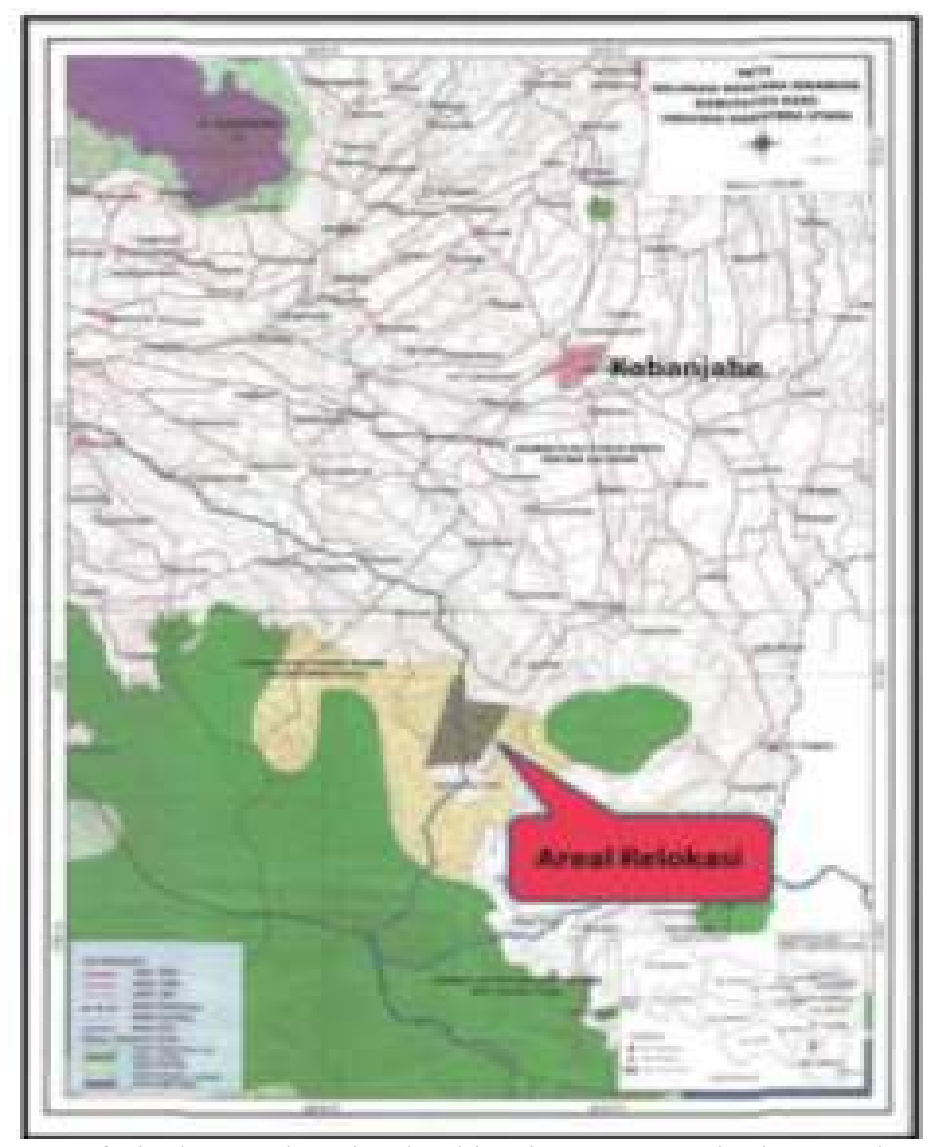

Fig. 1 Map of Sinabung relocation land in Siosar, Karo District, North Sumatra

Data collection and analysis using descriptive analysis by analyzing the results of interviewees. In this study in-depth interview techniques is used to ask several questions to the source of information. The data used in this study are primary and secondary data that will be obtained using data collection techniques, namely: (1) observation, the observation in this study is to observe the development of the extent to which the performance and achievement of the Mount Sinabung eruption refugee goal relocation specifically about the relocation to Siosar Village, Karo Regency, North Sumatra, (2) interview, are used as data collection techniques by using in-depth interview techniques in this study conducted by interviewing data sources by asking a number of questions to the information source, and (3) documentary studies. In this study are documents, records, profiles, official archives and other written data obtained by researchers from the Karo Regency North Sumatra BPBD office and the Mount Sinabung Eruption Disaster Victims Acceleration Unit of Mount Sinabung Karo District. The data analysis technique used by researchers in this study is a qualitative descriptive analysis technique, namely data obtained from observations and interviews then performed data reduction, presentation of data drawing conclusions and verification. 


\section{Result and discussion}

The relocation policy of the Mount Sinabung eruption victims is one of the policies carried out by the government as a form of disaster management efforts to overcome the problem of natural disasters. Phase I relocation in Siosar is intended for 2,053 households with an area of 250 hectares, including 3 villages that suffered severe damage during the Sinabung eruption, namely Sukameriah, Bakerah, and Simacem Village. The placement of the relocation of Mount Sinabung eruption victims into a residential area is aimed at ensuring that the village, cultural and social-political assets are not lost [7]. The government provides 0.5 ha / KK of land as agricultural land in the relocation area.

The status of ownership of agricultural land that will be given to the people to be relocated is the borrow-use system. However, at the beginning of the relocation process, the community was not willing to be relocated to Siosar because of the lack of available land for farming. Besides, Siosar land is also not good for horticultural agriculture. The condition of the former pine forests causes agricultural land to require land management before being used for farming. The community initially hesitated to be relocated, but with the condition of agricultural land completely buried after the eruption, as well as the severely damaged housing conditions, they were willing to move to the relocation area of Siosar. The picture of Siosar settlement conditions is presented in Figure 2. According to residents who occupy the Siosar settlement, the condition of available water is quite difficult and the color is slightly yellowish. 0.5 ha of agricultural land for each family is deemed insufficient to meet daily needs. Residents also have to adjust to the climate and soil conditions which are slightly different from the previous village.
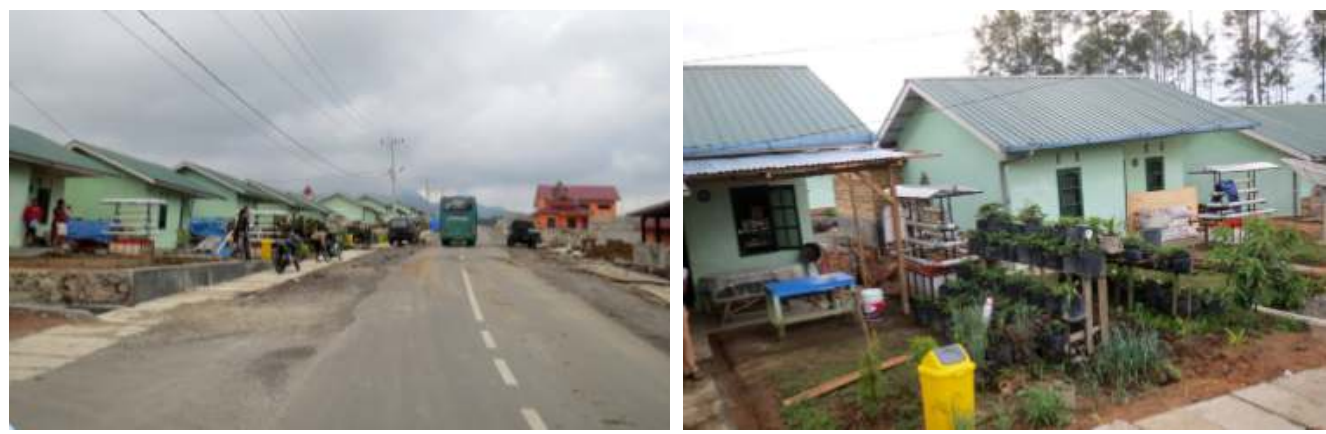

Fig. 2. Siosar relocation settlement

In this study, the social impact seen from the relocation policy of Mount Sinbung Eruption victims shows the process of changing the conditions of the community while in Siosar. Siosar relocation is occupied by 3 villages that have their village settings. When it was in the Siosar location, the village structure remained as before moving to the current location. The government recommends that 3 villages become one, but each village does not agree and continues to form the village layout into 3 villages in one relocation area. Each village head advocates unifying activities among residents, there is no difference between religions and mutual respect for one another. Customary activities continue to be carried out and preserved. And there is Jambur (meeting place for each village) which is still used by residents in Siosar. 
Initial conditions when the process of entering the Siosar area, the community experienced various obstacles, including the difficulty of the need for clean water, until the residents worked together to make a spring about $1 \mathrm{Km}$ from Siosar which was used to meet the needs of residents during the dry season. According to the Village Head of Simacem, from the beginning of the relocation until now there have been about 5 residents who died due to stress from the changes that occurred at the relocation site. Relocation is the only option when the initial village where they live can no longer be inhabited. However, over time, residents continue to try not to depend on the assistance provided by the government for those on Siosar. Each community helps each other to help and work together to meet all the needs of the community. Until now, people live in harmony with a variety of community diversity.

The economic impact in this discussion includes the impact of relocation on people's economic income while in Siosar Relocation. The majority of people who work as farmers claim that the distribution of 0.5 ha of land is deemed insufficient for each head of household. Coffee, which is the main commodity, has decreased, so that coffee fields must be added with vegetables to meet their daily needs. At the beginning of relocation, farmers need to adjust to the climate and land for crops planted by the community. When the drought struck, the harvest failed miserably and the farmers suffered a lot of losses. Sales of agricultural products must also be brought to Kabanjahe to get a standard selling price compared to direct sales on Siosar, which are much cheaper.

Each resident still receives subsidies for compost and seed fertilizer from the government with the help of 6 bags of compost / KK fertilizer. Besides, the village fund budget is also used for assistance to residents to purchase fertilizer and seedlings, if farmers lack fertilizer and the number of seeds to be planted, then they can buy privately to Kabanjahe. Besides, to meet their daily needs, besides farming some residents also become construction workers. Daily necessities that are a bit more expensive in Siosar are considered reasonable by the community because access to Kabanjahe is also quite far to get to Siosar. Efforts to be independent and no longer depend entirely on government assistance continue to be carried out by residents to fulfill their daily needs.

\section{Conclusion}

The relocation policy of Mount Sinabung Eruption victims in Siosar Karo District has a socio-economic impact that tends to be positive, although there are negative impacts that also occur. For the positive social impact that arises is the emergence of harmony among villagers in the Relocation area, the community works together and helps each other, and emerges the independence of each community not to depend on government assistance, and continues to preserve the customs of the Karo community in the new area lived in. The negative social impacts that occur only occur at the beginning of the relocation process, where agricultural land claims occur that are deemed insufficient to meet daily needs, but over time the community can adjust to the climate and conditions so that this does not happen again.

Whereas the economic impact tends to be slightly negative at the beginning in terms of the opinions of residents in relocation. Agricultural products harvested on 0.5 ha land are considered not able to meet the daily needs of residents, so they need side jobs besides farming in the Siosar area. Besides, to get the results of standard sales as usual farmers must bring their own to Kabanjahe compared to direct sales in Siosar at a much cheaper price. However, with the existing conditions, all people who are in the Siosar Relocation site feel 
grateful for the government's attention to provide shelter and provision of agricultural land and other subsidized farmer assistance, so that they can get back to living a decent life after the Mount Sinabung Eruption.

\section{References}

[1] Sukarman. 2015. Petunjuk Teknis Penanganan Lahan Relokasi Pengungsi Sinabung Di Siosar Kabupaten Karo Sumatera Utara. Jakarta: Badan Penelitian Dan Pengembangan Pertanian

[2] Nurjanna, Dkk. 2012. Manajemen Bencana. Bandung: Alfabeta.

[3] Yolanda, Yessi. 2016. Skripsi Evaluasi Kebijakan Relokasi Pengungsi Erupsi Gunung Sinabung Di Desa Siosar Kecamatan Merek Kabupaten Karo Provinsi Sumatera Utara. Lampung: Universitas Lampung

[4] (http://id.m.wikipedia.org/wiki/Sosial_ekonomi. Di akses pada tanggal 15 Mei 2019 pukul 13.52 WIB)

[5] Suri, Nur.K. 2015. Analisis Kinerja Badan Penanggulangan Bencana Daerah Kabupaten Karo Dalam Upaya Penanggulangan Bencana Erupsi Gunung Sinabung Di Kabupaten Karo. Jurnal Perpektif. Vol 8, No 1

[6] Pandia, Stenfry.L, dkk. 2016. Relokasi Permukiman Desa Suka Meriah Akibat Kejadian Erupsi Gunung Api Sinabung Kabupaten Karo. Jurnal Perencanaan Wilayah dan Kota.Vol. 27, no. 2, pp. $137-150$

[7] Nurwihastuti, Wahyuni, D.,dkk. 2019. Pengurangan Risiko Bencana Erupsi Gunung Sinabung. Yogyakarta: Elmatera 